\title{
Synthesis of Plans to Increase the Results of Ordinary National Education Test by All-Round Tutoring Process for Primary School Grade 6
}

\author{
Nuttakan Pakprod ${ }^{1}$, Kanokrat Jirasatjanukul ${ }^{2}$, Damrong Tumthong ${ }^{1}$, Prapa Amklad ${ }^{1} \&$ Wipa Lekchom ${ }^{1}$ \\ ${ }^{1}$ Faculty of Education, Phetchaburi Rajabhat University, Thailand \\ ${ }^{2}$ Faculty of Science and Technology, Phetchaburi Rajabhat University, Thailand \\ Correspondence: Nuttakan Pakprod, 38 Moo 8, Tambon Nawung, Amphoe Muang, Phetchaburi 76000, Thailand. \\ E-mail: nuttakan.pak@mail.pbru.ac.th
}

\author{
Received: August 19, $2020 \quad$ Accepted: October 10, $2020 \quad$ Online Published: January 27, 2021 \\ doi:10.5539/ies.v14n2p63 URL: https://doi.org/10.5539/ies.v14n2p63
}

\begin{abstract}
The objective of this research is to study the results of activities to increase the scores of Ordinary National Education Test. Cluster; teachers of Phetchaburi Rajabhat University comparing the results of Ordinary National Education Test in 2017-2018 and studying the satisfaction of the activities. The target group is 49 schools in Phetchaburi and Prachuap Khiri Khan Provinces, data were analyzed using mean and standard deviation. The study found that the difference of the scores of the Ordinary National Education Test was higher in 32 schools and there is a difference in scores of Ordinary National Education Test tests lower by 2 schools, representing 94.12, with the satisfaction of the participation in the activity of increasing the basic educational testing at the basic level is at a high level with an average of 4.22 , standard deviations 0.73 , which the participants are satisfied with the process. The process of organizing activities was at the highest with an average of 4.28 , standard deviations 0.76 and continues organizing activities to increase the scores of Ordinary National Education Test.
\end{abstract}

Keywords: ordinary national education test, all-round tutor, primary educational area

\section{Introduction}

\subsection{Introduce the Problem}

According to the learning standards in the core curriculum of basic education 2008 (O-NET: The National General Education Testing), the objective is to examine 5 defects. 1) Used as part of graduating from the basic education curriculum 2008, 2) Use as a subject in studies for the selection of people to study at a higher level 3) Used to improve the quality of teaching and learning of the school. 4) Used to assess national student learning and 5) Use of O-NET test results for other purposes to make every school in Thailand focusing on creating a process so that all students can pass the Ordinary National Education Test.

\subsection{Explore Importance of the Problem}

In 2018 the test results show that Thai language subject has an average score of 55.90, the English subject has an average score of 39.24, the mathematics subject has an average score of 37.50, and the science subject has an average score of 39.93 (Ordinary National Education Test, 2019) that does not pass the criteria of 50 percent as specified by the Ministry of Education.

\subsection{Describe Relevant Scholarship}

According to the problems, Phetchaburi Rajabhat University, which has a determination as a local wisdom centre, sees the importance of the development of such an all-round process. The university therefore develops students in the teaching profession that can use the knowledge of the university to meet the needs of the local educational institutions Develop teachers stationed in the locality to urgently solve problems and develop students who are the most important people in self-development Phetchaburi Rajabhat University has set up a working group to carry out activities to increase the results of Ordinary National Education Test testing in 2019. The results of the activities from the participants of 30 schools have higher scores than 50 points, 26 schools, accounting for 86.66 percent. However, from the survey of the opinions of the interested persons of educational personnel in Phetchaburi and Prachuap Khiri Khan Found negative comments divided into 3 points as follows 1) Lacking of 
clear criteria for selection of participants 2) Lacking of participation of stakeholders and 3) The developing process is lacking in sustainability.

\subsection{State Hypotheses and Their Correspondence to Research Design}

Increasing activity outcomes and reducing negative feedback requires activities to be formulated to increase O-Net's scores by the all-round tutoring process for grade 6 students. The synthesis of the O-Net plan for increasing O-Net's scores by the all-round tutoring process for grade 6 students in Phetchaburi and Prachuap Khirikhan, Thailand.

\section{Method}

To synthesize a plan to increase the results of Ordinary National Education Test (O-Net) with the all-round tutoring process for grade 6 students.

The target groups were 20 schools in Phetchaburi and Prachuap Khiri Khan provinces, which were selected by simple random sampling. In Phetchaburi and Prachuap Khiri Khan provinces.

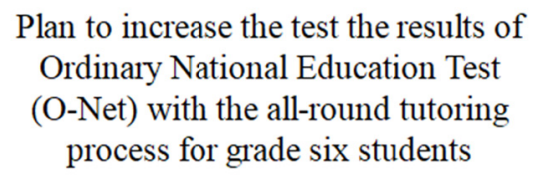

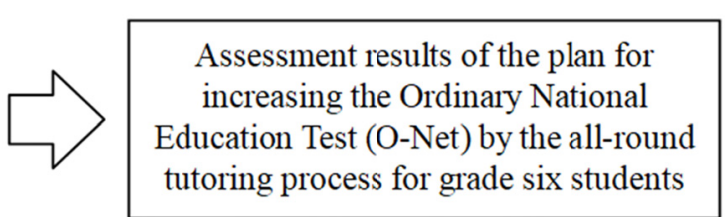

Figure 1. Conceptual framework of research

The synthesis of the O-Net plan for enhancing the results of basic national educational testing with an all-round tutoring process for grade 6 students is an action research and development process. The research methods are divided into 6 phases.

Phase 1: Study of concepts and theories; organize a community forum to listen to opinions on the formulation of activities to increase the results of Ordinary National Education Test (O-Net) and to study the format of activities to increase the basic educational test results at the basic level in the fiscal year 2019.

Phase 2: Using the data from Phase 1, including the opinions of participants of the activity with the first model, the activity process in Phetchaburi Province with the second model, the activity process in Prachuap Khiri Khan, Results Ordinary National Education Test (O-Net) and satisfaction of the participants The synthesis plan was to increase the results of the national basic educational test $(\mathrm{O}-\mathrm{Net})$ with an all-round tutoring process for grade 6 students

Phase 3: Revise the plan to increase the results of Ordinary National Education Test (O-Net) properly with the all-round tutoring process for grade 6 students from the group of activity administrators, activity advisor, educational experts and students of Phetchaburi Rajabhat University to suit the context of the working group and the operational management system within Phetchaburi Rajabhat University

Phase 4: Revised the plan to increase the results of the Ordinary National Education Test (O-Net) with the all-round tutoring process for grade 6 students in Phase 3 and then assessed the suitability by 3 experts

Phase 5: The Ordinary National Education Test's Plan with all-round tutoring process for grade 6 students from experts was improved as you can see in figure 2 .

Phase 6: The plan for increasing Ordinary National Education Test (O-Net) results proposed in order to carry out the activities can summarize the following details:

Cluster Teacher: The group responsible for coordinating the activities:

\section{Budget: The Department of Academic Services}

The main indicators: the Ordinary National Education Test's score of a participating school activities must get higher than the provincial average of 100 percent.

The date and place: Table 1. 


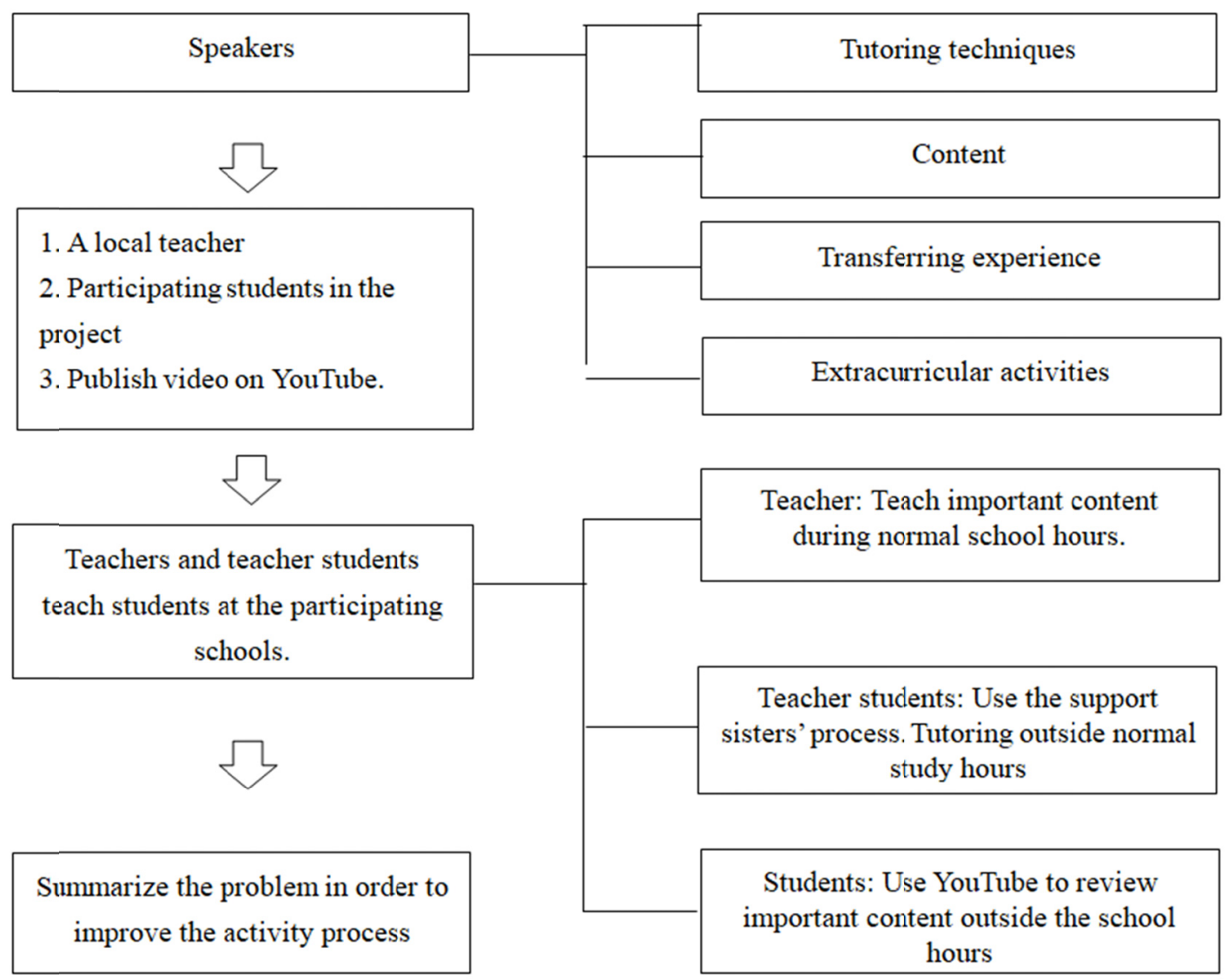

Figure 2. The process of increasing the results of the Ordinary National Education Test $(\mathrm{O}-\mathrm{Net})$ with the all-round tutoring process for grade 6 students

From Figure 2, it can explained that there are four functional division mechanisms, youtube Activity Workshop Training. First, speakers will provide knowledge about tutoring techniques, content, transferring experience and extracurricular activities. Second, local teacher and participating students in the project will publish video on YouTube. Next step local teachers and students in the project at the participating schools. Teacher teaches important content during normal school hours. Teacher students or students in the project use the support sisters' process. Tutoring outside normal study hours. In addition, students in school use youtube to review important content outside the school hours. Final, we are summarizing the problem in order to improve the activity process. 
Table 1. Proceed, dates and locations for increasing Ordinary National Education Test (O-Net) results

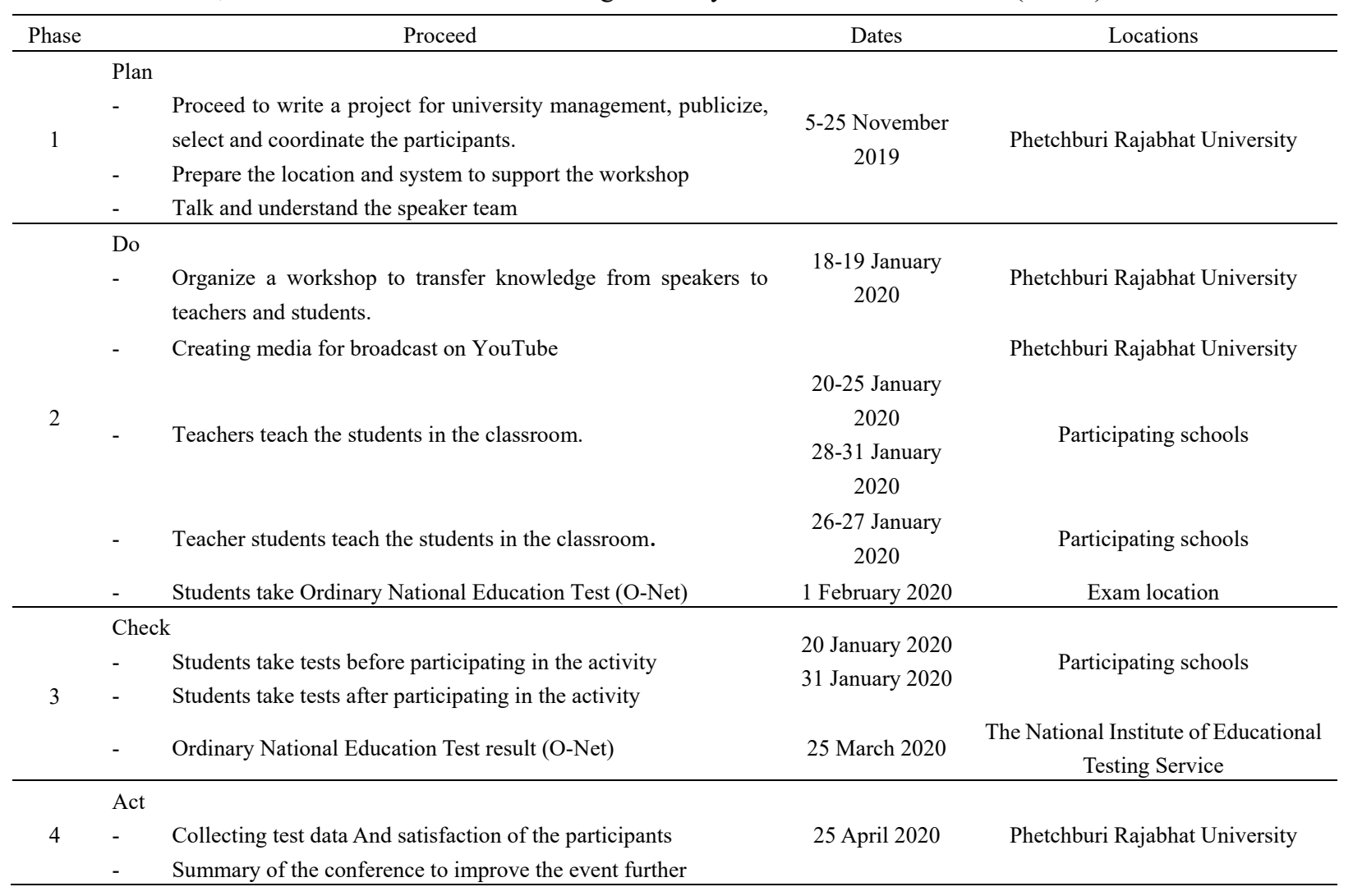

\section{Results}

Synthesis of plans to increase the results of ordinary national education test by all-round tutoring process for primary school grade 6. The target groups were 20 schools in Phetchaburi and Prachuap Khiri Khan Provinces, which were selected by simple random sampling. In Phetchaburi and Prachuap Khiri Khan Provinces, the total average of evaluation results was at high level. In addition, the experts suggested that the university should have a mechanic to support the second quarters the activities for more convenience, speed, and school's need.

\subsection{Recruitment}

The evaluation results were show in Table 2.

Table 2. The evaluation results in appropriateness of the plans to increase the results of ordinary national education test by all-round tutoring process for primary school grade 6

\begin{tabular}{lccc}
\hline \multirow{2}{*}{ Appropriateness } & \multicolumn{2}{c}{ Opinion Level } & \multirow{2}{*}{ Appropriateness Level } \\
\cline { 2 - 4 } & $\bar{x}$ & S.D. & More \\
1. Activity Duration & 4.20 & 0.63 & More \\
2. Activity Budget & 4.40 & 0.70 & More \\
3. Participants' Cooperation and Participation & 4.40 & 0.52 & More \\
4. Measurement and Evaluation of Teaching Model & 4.30 & 0.48 & More \\
5. Activity's Overall Benefit & 4.33 & 0.50 & Most \\
6. Benefit of teacher' activity & 4.56 & 0.53 & More \\
7. Benefit of undergraduate student's activity & 4.44 & 0.53 & Most \\
8. Benefit of student's activity & 4.60 & 0.52 & More \\
9. Sustainability in Development & 4.33 & 0.50 & Most \\
10. Participants Satisfaction & 4.61 & 0.53 & More \\
Total Average & 4.42 & 0.54 & \\
\hline
\end{tabular}

Table 2 showed the evaluation results in appropriateness of the plans to increase the results of ordinary national 
education test by all-round tutoring process for primary school grade 6 . The total average of evaluation results was at high level $(\bar{x}=4.42$, S.D. $=0.54)$. The participants satisfaction was at the highest level $(\bar{x}=4.61$, S.D. $=0.53)$. However, the activity duration was at the lowest level $(\bar{x}=4.20$, S.D. $=0.63)$. Moreover, the experts suggested that the university should have a mechanic to support the second quarters the activities for more convenience, speed, and school's need.

\subsection{Statistics and Data Analysis}

The research instrument used for this study was an evaluation form of the plans to increase the results of ordinary national education test by all-round tutoring process for primary school grade 6 using Likert's scale 5 points. Statistic in this research used the average value and standard deviation.

$\begin{array}{lll}\begin{array}{lll}\text { Feasibility Analysis } & & \\ \text { Scoring Criteria } & \text { Most } & =5 \\ & \text { More } & =4 \\ & \text { Moderate } & =3 \\ & \text { Low } & =2 \\ & \text { Very low } & =1\end{array} \\ \text { Evaluation criteria } & \text { Most } & 4.50-5.00 \\ & \text { More } & 3.50-4.49 \\ & \text { Moderate } & 2.50-3.49 \\ & \text { Low } & 1.50-2.49 \\ & \text { Very low } & 1.00-1.49 \\ \text { Average Value } & & \bar{x}=\frac{\sum x}{n} \\ \text { Standard Deviation } & \text { S. D. }=\sqrt{\frac{\sum\left(x_{i-\bar{x}}\right)^{2}}{(n-1)}}\end{array}$

\section{Discussion}

Based on the experts' evaluation results in appropriateness of the plans to increase the results of ordinary national education test by all-round tutoring process for primary school grade 6, the participants' satisfaction was at the highest level. However, the activity duration was at the lowest level. The experts also gave the suggestion for the activity duration because of a disbursement budget problem.

Furthermore, the overall appropriateness of the plans to increase the results of ordinary national education test by all-round tutoring process for primary school grade 6 was at the high level. There are two main reasons. First, a model of activity management and tutoring process were used for synthesizing the plans. The model was used for increasing the results of ordinary national education test in 2019. The tutoring process was found from the researches named the role of questioning in writing tutorials: a critical approach to student-centered learning in peer tutorials in higher education (Munje et al., 2018) and AVID Tutorial Process (Luka, 2011). Second, the activity results were used for interviewing people in order to synthesis a new plan to raise the ordinary national education test outcome. Also, P-D-C-A process was used as an activity guideline (McLaughlin, Gerald W.; Snyder, 2013). The first step of the process was Plan. All participations specified a duration, place, personnel and budget. The second step was Do, following the plan. The third step was Check, checking the results and effects. The fourth step was Act. All data were collected as a database for increasing an efficiency of next activity.

\section{Acknowledgments}

The Synthesis of plans to increase the results of ordinary national education test by all-round tutoring process for primary school grade 6, activities outcomes, teachers cluster of Phetchaburi Rajabhat University were created by two resources. The first resource was the teachers cluster's cooperation. The cluster was composed of a Faculty of Education, Faculty of Humanities and Social Sciences, Faculty of Science, and Faculty of Science in Information Technology at Phetchaburi Rajabhat University. The second resource was Phetchaburi Educational Service Area, 
Prachuap Khiri Khan Educational Service Area, school directors, and teachers.

\section{References}

Alicia L., H., Chris, G., \& Reshma, D. (2017). Coaching tutors: An Instrumental Case study on testing an integrated framework for tutoring sessions. JCITT, 1(1), 4-12. https://doi.org/10.26878/2017/100003

Cluster Teacher. (2562). Report on the implementation of the local development project according to the king's science.

Ko, W.-H., \& Chen, C.-Y. (2017). To Explore the Research and Development Competence and School-to-Work Transition for Hospitality Students. Journal of Education and Training Studies, 5(12), 120. https://doi.org/10.11114/jets.v5i12.2808

Luka, S. (2011). AVID Tutorial Process. Retrieved from https://www.slideserve.com/luka/avid-tutorial-process

McLaughlin, G. W., \& Snyder, J. K. (2013). Plan-Do-Check-Act and the Management of Institutional Research. AIR 1992 Annual Forum Paper. Journal of Chemical Information and Modeling, 53(9), 1689-1699. https://doi.org/10.1017/CBO9781107415324.004

Munje, P. N., Nanima, R. D., \& Clarence, S. (2018). The role of questioning in writing tutorials: a critical approach to student-centered learning in peer tutorials in higher education. Mentoring and Tutoring: Partnership in Learning, 26(3), 336-353. https://doi.org/10.1080/13611267.2018.1511953

Perry, J., \& Luk, A. (2018). VOLUNTEER TUTORS: AGENTS OF CHANGE OR REPRODUCTION? AN EXAMINATION OF CONSCIOUSNESS, IDEOLOGY, AND PRAXIS. CJSAE the Canadian Journal for the Study of Adult Education, 30(1), 19-32.

\section{Copyrights}

Copyright for this article is retained by the author(s), with first publication rights granted to the journal.

This is an open-access article distributed under the terms and conditions of the Creative Commons Attribution license (http://creativecommons.org/licenses/by/4.0/). 